\title{
Dietary vegetable oils do not alter the intestine transcriptome of gilthead sea bream (Sparus aurata), but modulate the transcriptomic response to infection with Enteromyxum leei
}

\author{
Josep A Calduch-Giner ${ }^{1}$, Ariadna Sitjà-Bobadilla², Grace C Davey ${ }^{3}$, Michael T Cairns ${ }^{3}$, Sadasivam Kaushik ${ }^{4}$
} and Jaume Pérez-Sánchez ${ }^{1 *}$

\begin{abstract}
Background: Studies conducted with gilthead sea bream (Sparus aurata L.) have determined the maximum dietary replacement of fish meal and oil without compromising growth or product quality. The present study aimed to analyze the effect of the nutritional background on fish health and fish fed plant protein-based diets with fish oil (FO diet) or a blend of vegetable oils (66VO diet) were exposed for 102 days to the intestinal myxosporean parasite Enteromyxum leei, and the intestine transcriptome was analyzed with a customized oligo-microarray of 7,500 annotated genes.

Results: Infection prevalence was high and similar in the two diet groups, but the outcome of the disease was more pronounced in fish fed the 66VO diet. No differences were found in the transcriptome of both diet control groups, whereas the number of differentially expressed genes in infected groups was considerable. K-means clustering of these differentially expressed genes identified four expression patterns that reflected the progression of the disease with the magnitude of the fold-change being higher in infected 66VO fish. A positive correlation was found between the time of infection and the magnitude of the transcriptional change within the $66 \mathrm{VO}$ group, being higher in early infected animals. Within this diet group, a strong up-regulation of many components of the immune specific response was evidenced, whereas other genes related to complement response and xenobiotic metabolism were down-regulated.

Conclusions: The high replacement of fish oil by vegetable oils in practical fish feeds did not modify the intestine transcriptome of gilthead sea bream, but important changes were apparent when fish were exposed to the myxosporean E. leei. The detected changes were mostly a consequence rather than a cause of the different disease progression in the two diet groups. Hence, the developed microarray constitutes an excellent diagnostic tool to address changes associated with the action of intestinal pathogens, but lacks a prognostic value to predict in advance the different susceptibility of growing fish to the current pathogen.
\end{abstract}

Keywords: Teleost, Parasite, Myxozoa, Intestine, Transcriptome, Nutrigenomics

\footnotetext{
* Correspondence: jperez@iats.csic.es

${ }^{1}$ Nutrigenomics and Fish Growth Endocrinology Group, Department of Marine Species Biology, Culture and Pathology, Instituto de Acuicultura Torre de la Sal (IATS-CSIC), Ribera de Cabanes, Castellón 12595, Spain

Full list of author information is available at the end of the article
} 


\section{Background}

The increased demand for fish meal and fish oil to meet the requirements of expanding aquaculture and other farming industries has led to the search for alternative raw materials. Attention has been focused on plant ingredients and studies conducted in gilthead sea bream (GSB) (Sparus aurata L.) have demonstrated that the combined replacement of fish meal and fish oil (FO) is highly feasible without detrimental effects in growth performance when the theoretical requirements for essential amino acids and fatty acids are met by the diet $[1,2]$. However, obvious changes in muscle fatty acid (FA) signatures occur with the replacement of FO by vegetable oils (VO) [3-5] and a wash-out period with fish oil-based diets is needed for the restoration of the desired FA profile having a high concentration of $n-3$ long-chain polyunsaturated FAs [6].

The effect of the nutritional background on fish health and welfare also merits careful consideration and there is much interest for research in this area in the recent years (reviewed in [7]). Indeed, adequate nutrition is essential to maintain health and to reduce disease susceptibility and pathological changes, and dietary lipids, as other nutritional factors, have specific actions on the immune response $[8,9]$. In GSB, it is noteworthy that the redox balance [10] and the cortisol response after stress confinement [11] were altered by the high replacement of FO by VOs. Even lower VO replacement levels (50-60\%) increased the cumulative mortality in GSB challenged with Vibrio alginolyticus or increased the intestine expression of TNF- $\alpha$ in Photobacterium damselae subsp. piscicida injected animals (see [9]). Furthermore, fish fed with a diet rich in $\mathrm{VO}$ exhibited a worse disease outcome when challenged with the intestinal parasite Enteromyxum leei, consisting in lower biometrical (weight, condition factor, specific growth rate), immunological (haematocrit, complement and lysozyme activity) and antioxidant (hepatic total glutathione) parameters compared to infected fish fed a FO diet [12]. In an effort to understand the possible underlying mechanisms involved in this greater progression of the infection in VO fish, we undertook a series of detailed studies of gut immunology and physiology in fish fed plant- or fishbased diets and challenged with this myxosporean. This intestinal parasite causes severe desquamative enteritis and thus far there are no preventive or curative treatments for this enteromyxosis. However, a few select inflammatory and immune relevant genes have been initially explored [13,14], and more recently the molecular profiling with a cDNA microarray of the host response to the chronic exposure to E. leei has highlighted a complex interplay of proteases, protease inhibitors, apoptotic factors as well as cell proliferation and antioxidant defence genes [15]. The same array has also proven to be very useful for assessing the time course of stress response after confinement exposure [16], and herein the transcriptome database which served for the construction of these arrays was further enriched by suppression subtractive hybridization (SSH) libraries with lipid-responsive genes. All sequences were de novo assembled and the final annotated sequences were used to construct a customized oligo-array for expression profiling of the GSB intestine using a factorial design $(2 \times 2)$ with diet composition and parasite infection as experimental variables. To pursue this issue, juvenile GSB fed plant protein-based diets with either FO diet or a blend of VOs (66VO diet) as a major dietary lipid source were infected with the intestinal parasite E. leei by water effluent and the intestinal transcriptome of the host was analyzed 102 days post-challenge.

\section{Results}

\section{Microarray profiling}

Principal component analysis of microarray results revealed that the first two components accounted for the $89 \%$ of total variation (Figure 1). Much of the variation (83\%) was explained by component 1 , which primarily separated three main groups according to the progression of infection: i) control fish fed FO (FO-C) and 66VO diets $(66 \mathrm{VO}-\mathrm{C})$, ii) FO-recipients with early $\left(\mathrm{FO}-\mathrm{INF}_{\mathrm{E}}\right)$ or late $\left(\mathrm{FO}-\mathrm{INF}_{\mathrm{E}}\right)$ infection, and iii) $66 \mathrm{VO}$-recipients with early $\left(66 \mathrm{VO}-\mathrm{INF}_{\mathrm{E}}\right)$ or late $\left(66 \mathrm{VO}-\mathrm{INF}_{\mathrm{E}}\right)$ infection. More than 2,000 unique sequences were differentially expressed when comparisons were made among all groups (corrected P-value $<0.05$, Benjamini-Hochberg), but interestingly only one gene was differentially expressed when comparisons were made between FO-C and 66VO-C groups. Among the differentially expressed genes, 110 were derived from the SSH libraries enriched with lipid-responsive genes.

The k-means clustering of differentially expressed genes identified four major expression patterns or clusters (Figure 2). The entire sets of genes included in each cluster are listed in an additional file (Additional file 1: Table S1) with fold-change expression values referred to the FO-C group. Cluster 1 was composed of 88 genes that were strongly up-regulated in early and late infected fish (fold-change $>500$ ). Gene Ontology (GO) and Fisher enrichment analyses did not show relevant GO categories for cluster 1 that included, among others, carbonic anhydrase 9, arginase-1 and many proteases and ribosomal proteins. A second group of up-regulated genes (foldchange 2.0-4.0) were grouped in cluster 2 (838 genes) that was significantly enriched $(\mathrm{P}<0.05)$ in $\mathrm{GO}$ terms related to "translation", "RNA processing", "mitotic cell cycle" and "cell cycle" with a high representation of urea cycle and polyamine biosynthetic pathway 


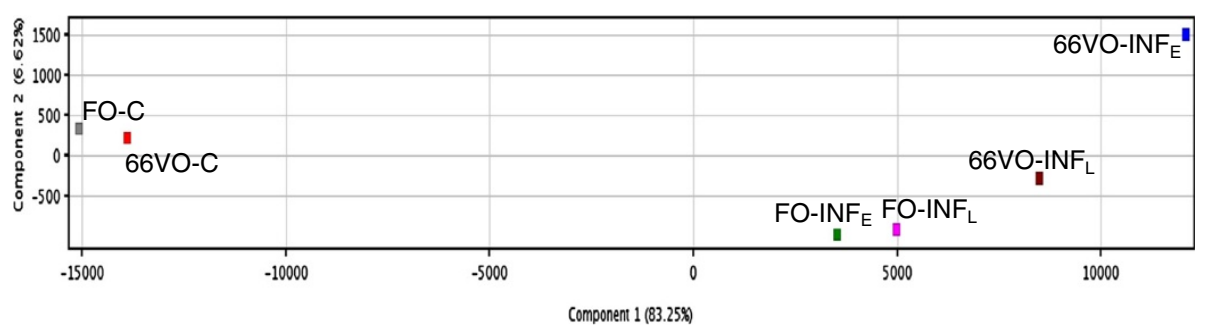

\begin{tabular}{|c|c|c|c|c|c|c|}
\hline Group Name & FO-C & FO-INF $_{\mathrm{L}}$ & FO-INF $_{\mathrm{E}}$ & $66 \mathrm{VO}-\mathrm{C}$ & 66VO-INF $_{\mathrm{L}}$ & 66VO-INF $_{\mathrm{E}}$ \\
\hline FO-C & --- & 455 & 359 & 1 & 908 & 1392 \\
\hline FO-INF $_{\mathrm{L}}$ & & --- & 2 & 338 & 5 & 117 \\
\hline FO-INF $_{\mathrm{E}}$ & & & --- & 253 & 7 & 131 \\
\hline $66 \mathrm{VO}-\mathrm{C}$ & & & & --- & 787 & 1292 \\
\hline 66VO-INF & & & & & --- & 36 \\
\hline 66VO-INF $_{\mathrm{E}}$ & & & & & & --- \\
\hline
\end{tabular}

Figure 1 Principal components analysis of gut transcriptome after nutritional and parasite challenges. The number of differentially expressed genes among experimental groups was determined by one-way ANOVA (corrected P-value $<0.05$, Benjamini-Hochberg).

genes (ornithine aminotransferase, ornithine carbamoyltranferase, ornithine decarboxylase), immunoglobulins and cytokines, including interleukin-6 (IL6), IL6 receptor and interferon-related proteins.
Strongly and moderately down-regulated genes were included in cluster 3 and 4, respectively. Cluster 3 contained 247 genes (fold-change 0.1-0.4) enriched in the GO categories "oxidation-reduction" and "cellular lipid
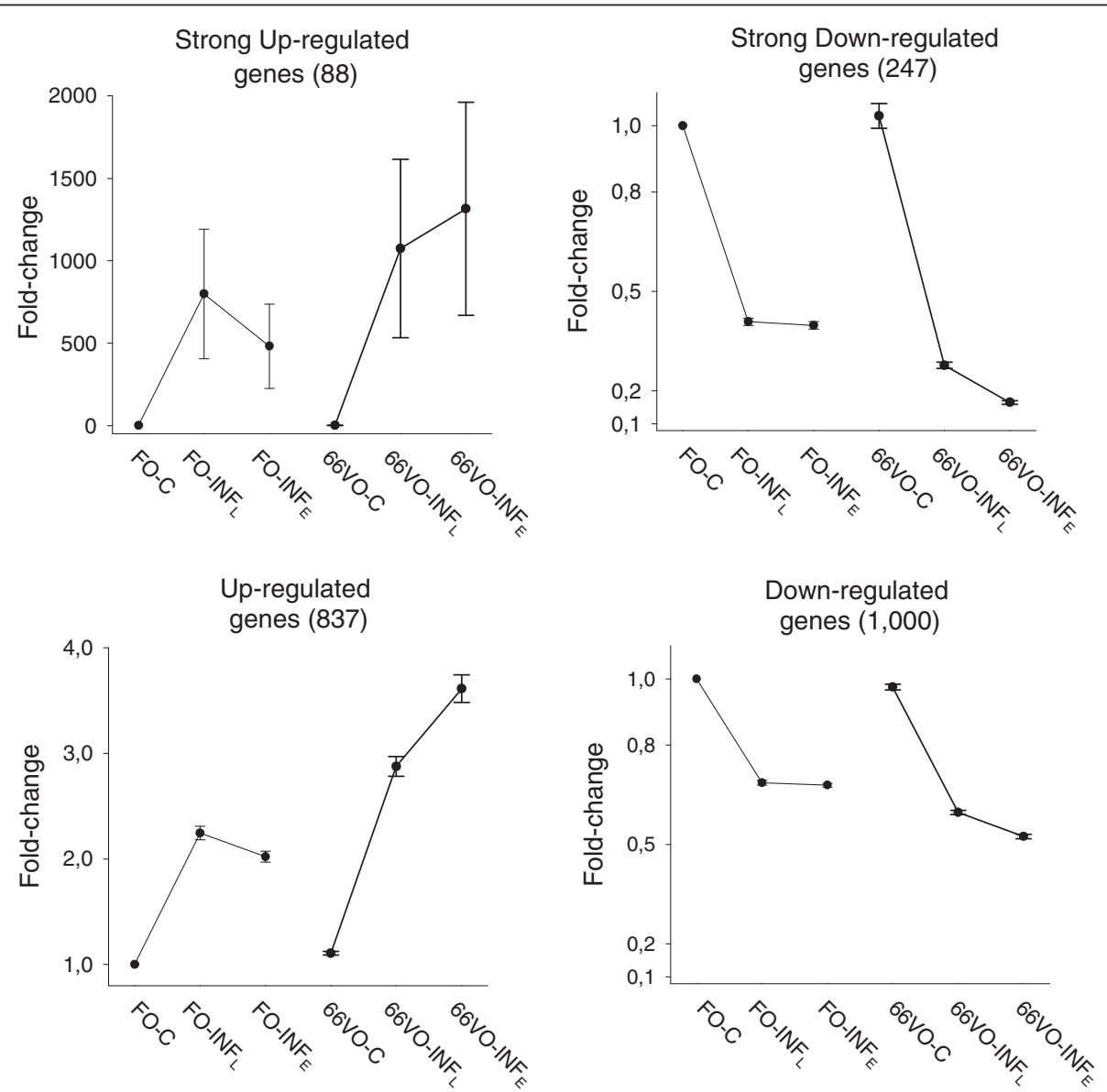

Figure 2 K-means analysis of differentially expressed genes in the diet groups after parasite challenge. The FO-C group was used as reference for fold-change calculations. Values are the mean \pm SEM. For each cluster group, the number of differentially expressed genes is in parenthesis. 
metabolic process" $(\mathrm{P}<0.05)$. In particular, $\mathrm{P} 450$ detoxifying enzymes, phospholipase A2, intestinal fatty acid binding protein (FABP2), uncoupling protein 1 (UCP1) and many complement related factors, such as complement $\mathrm{C} 1 \mathrm{q}$ tumor necrosis factor-related protein 3 , complement factor $\mathrm{H}$, complement factor $\mathrm{C} 2$, lectin and fucolectin-1. Cluster 4 was the most abundant group with 1,000 differentially expressed genes that exhibited a moderate down-regulation (fold-change 0.5-0.7) in response to infection. This cluster was significantly enriched $(\mathrm{P}<0.05)$ in genes with the GO categories "signal transduction", "positive regulation of cellular process", "cell differentiation" and "regulation of RNA metabolic process", and included among others several growth factors such as insulin-like growth factor II (IGF-II), growth hormone receptors type I (GHR-I) and II (GHR-II) and IGF binding-protein 4 (IGFBP4).

As a general rule, the k-means cluster analysis also showed that the magnitude of change for differentially expressed genes was highest in E. leei-challenged fish in the 66VO group, which also exhibited a higher and faster disease progression (for details see [12]). In addition, within the 66VO group, the magnitude of transcriptional change was more pronounced in early infected fish $\left(66 \mathrm{VO}-\mathrm{INF}_{\mathrm{E}}\right)$ than in those infected later $\left(66 \mathrm{VO}-\mathrm{INF}_{\mathrm{E}}\right)$. This was particularly evident when differentially expressed genes (clusters 2, 3 and 4) in early infected fish $\left(66 \mathrm{VO}-\mathrm{INF}_{\mathrm{E}}, \mathrm{X}\right.$-axis) were plotted against the gene expression profile of late infected fish $\left(66 \mathrm{VO}-\mathrm{INF}_{\mathrm{L}}\right.$, Y-axis), evidencing a very good linear correlation $(r=0.95)$ (Figure 3). However, the detailed analysis of the correlation showed that some genes deviate from the predictions (shaded areas in Figure 3). This was the case for genes related to the production of immunoglobulins, which were more over-expressed than envisaged in early-infected $66 \mathrm{VO}$ fish, whereas those related with the complement pathway (lectin, fucolectin-1, complement $\mathrm{C} 1 \mathrm{q}$ tumor necrosis factor-related protein 3) and the metabolism of xenobiotics (cytochrome P450 1A1, cytochrome P450 2J6) were more under-expressed than expected. This means that some genes are particularly up- or down-regulated after prolonged time of infection.

\section{Functional annotation}

Given that the major disease outcome was observed in $66 \mathrm{VO}-\mathrm{INF}_{\mathrm{E}}$ fish, pathway analysis by means of IPA software focused on this group (Figure 4). For the top ten biological functions, more than $65 \%$ were represented by down-regulated genes (green bars), which was the case for protein synthesis, protein degradation, small molecule biochemistry, lipid metabolism, cancer and carbohydrate metabolism. By contrast, other biological functions, including amino acid metabolism, RNA post-transcriptional modification, infection mechanism and infectious disease were mostly equally or slightly over-represented in the group of up-regulated genes (red bars).

\section{Real time qPCR validation}

Microarray results were validated for a large number of differentially expressed genes in fish from each diet group (Figure 5). There was a strong linear correlation

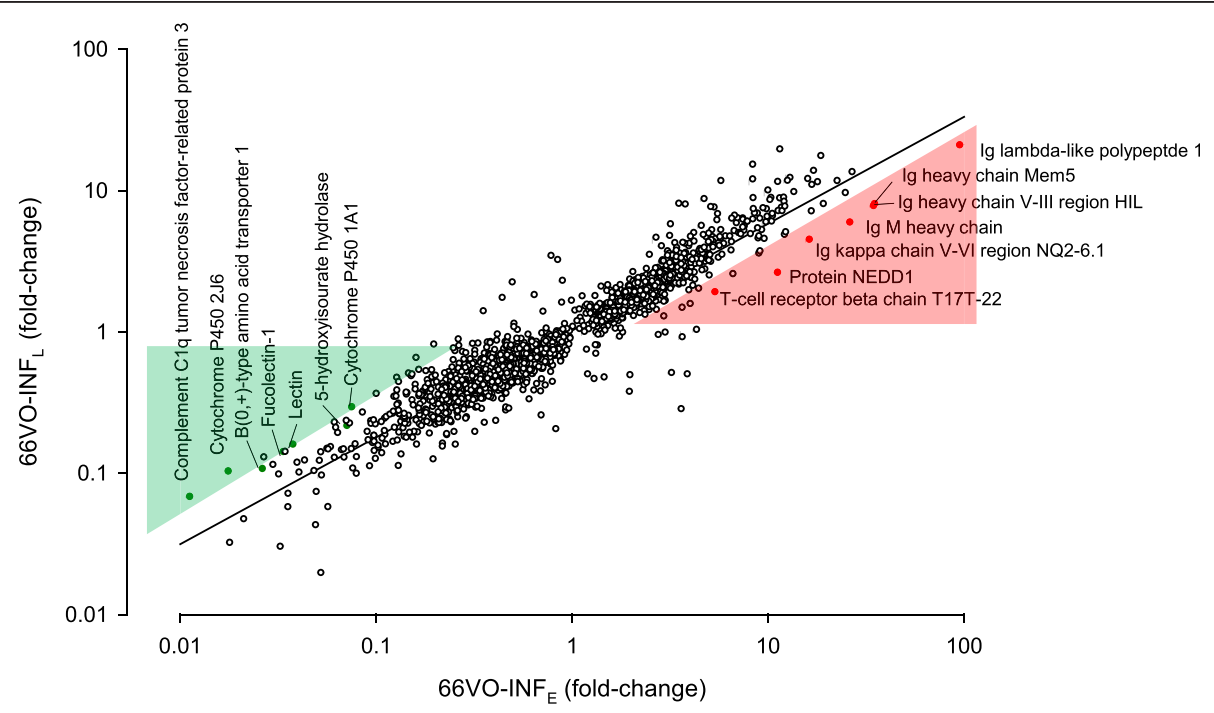

Figure 3 Correlation of the gene expression pattern for differentially expressed genes of clusters 2,3 and 4 in early (66VO-INF $\mathrm{E}_{\mathrm{E}} \mathrm{X}$-axis) and late infected fish (66VO-INF, $\mathrm{Y}$-axis) fed the $66 \mathrm{VO}$ diet. The FO-C group was used as reference for fold-change calculations. Shaded areas mark genes that are particularly up- (red) or down-regulated (green) after prolonged time of infection. 


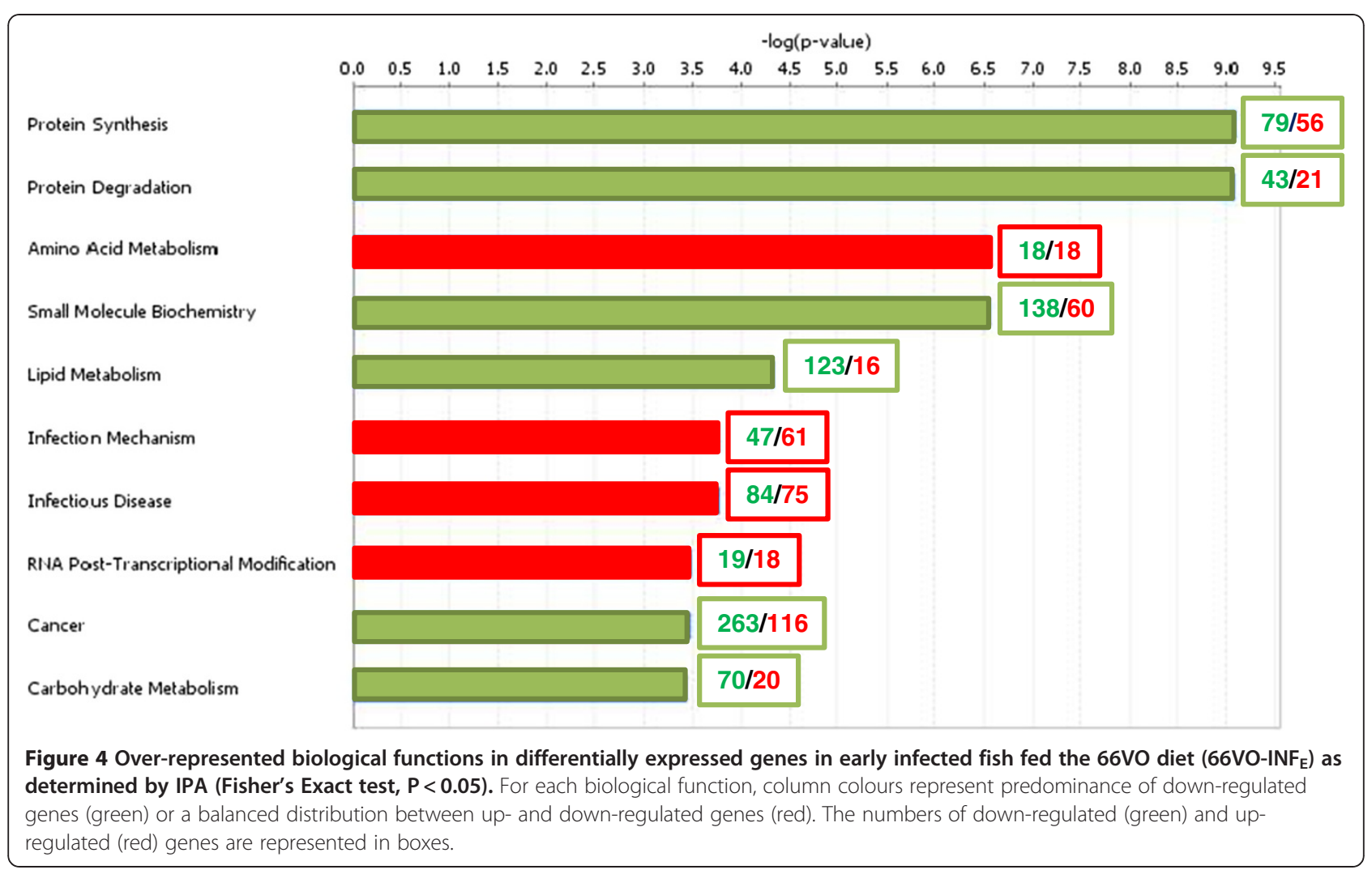

between microarray and qPCR results, though genes with the highest level of expression (e.g., arginase-1 and immunoglobulin lambda-like polypeptide 1) were slightly over-estimated in the microarray in comparison to the results of qPCR.

\section{Discussion}

To date, a considerable number of studies have been conducted in fish to identify target genes of relevance for the improvement of production traits of farmed fish species (reviewed in [17-19]). The liver, due to its major
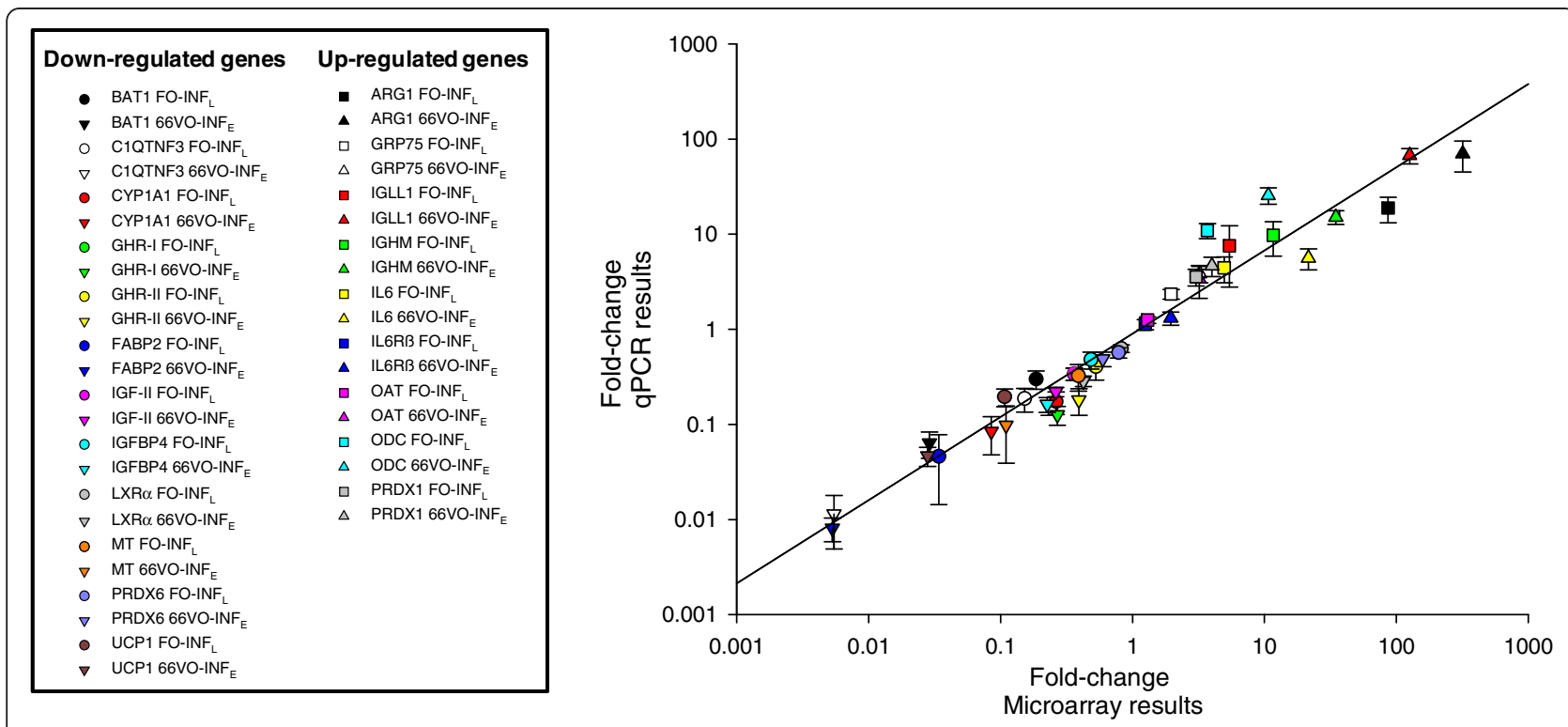

Figure 5 Real-time qPCR validation of microarray results. Correlation plot of fold-change values for the selected genes analyzed by microarray (X-axis) and qPCR methodologies (Y-axis) in infected fish fed FO and 66VO diets. The FO-C group was used as reference for foldchange calculations. To simplify the graph representation mean deviations (mean \pm SEM) are only represented for qPCR data. 
role in metabolism, has been the main studied tissue in fish genome-wide analyses with special attention to stress response [16,20,21], ecotoxicology [22-24] or nutrigenomics [25-28]. Transcriptome responses involving the fish immune system after bacterial or viral experimental challenges have also been assessed in liver, although the main studied tissue for this purpose is the head kidney because of its central hematopoietic role, equivalent to that of mammalian bone marrow [29-31]. The fish intestine, besides its importance for the absorption of nutrients and osmoregulation, also acts as an immune tissue and constitutes a barrier and first line of defence against certain pathogens and environmental challenges [32,33], so the gene expression profile of the intestine in nutritional and/or pathogenic trials should be specially considered. However, very few transcriptome-wide studies have paid attention to the response of fish gut, being focused these approaches on salinity adaptation in European eel (Anguilla anguilla) [34], and phosphorus deficiencies and dietary immunostimulants in rainbow trout (Oncorhynchus mykiss) [35,36] or replacement of fish meal and FO in diets for Atlantic halibut (Hippoglossus hippoglossus), Atlantic salmon (Salmo salar), and Atlantic cod (Gadus morhua) [37-39].

In GSB, the host response to chronic exposure to $E$. leei was previously analyzed in both intestine and head kidney by transcriptome profiling of few candidate genes [14], and more recently [15] by means of a cDNA microarray that was previously proven successful to assess the response of the liver of fish undergoing confinement exposure [16]. The oligo-microarray designed and used in the current work was developed from these previous annotated nucleotide sequences updated with lipidresponsive genes by means of a SSH approach in order to have a wide range of genes potentially regulated by nutritional deficiencies in essential fatty acids. In this scenario, it must be noted that this is the first attempt to analyze the combined effect of diet and parasite infection on the fish intestinal transcriptome. The detected massive transcriptome changes can be mainly attributed to the progression of the infection, but not to the dietary treatment, since no differences between diet groups were found in the intestine transcriptome of control animals (not exposed to the parasite) as revealed by the one-way ANOVA and principal components analysis. Furthermore, both control diet groups showed similar growth performance with no evidences of hepatic and intestinal histopathology, probably due to the adequate supplementation of diets with soy-lecithin as an extra-source of dietary phospholipids [2,3]. By contrast, in Atlantic salmon and Atlantic cod, the adverse effects of dietary soybean meal leading to intestinal disorders (inflammation and lipid accumulation) were also accompanied by changes in the intestine transcriptome $[38,39]$.
In our experimental model, intestine transcriptomic differences between diets only became evident when animals were infected with the parasite, as the number of differentially expressed genes and the degree of foldchange variations were much higher in animals fed the $66 \mathrm{VO}$ diet than in those fed the FO diet, which paralleled the increased symptoms of enteromyxosis (lower growth, condition factor and haematocrit in combination with higher anorexia, and intensity and extension of the infection) in parasitized fish of this diet group [12]. Furthermore, the gene expression profile determined by kmeans clustering also emphasizes the importance of the progression of the infection, with a stronger effect in terms of fold-change variation in infected animals fed the 66VO diet, and even more in early infected fish. This reinforces the idea that the microarray used in the present study constitutes an excellent diagnostic tool to address changes associated with the action of the pathogen.

When analyzing the biological functions of the genes differentially expressed upon infection, it was evident that the infection produced a detrimental effect on many pathways related to growth and normal metabolism, as genes related to protein synthesis, protein degradation, small molecule biochemistry, lipid metabolism, cancer and carbohydrate metabolism were down-regulated. By contrast, other biological functions, related to infection mechanism, infectious disease and immune response were over-represented by up-regulated genes. It is difficult to compare the current results with those obtained in other fish-pathogen models, since the host-pathogen interactions are different and the times post-infection at which the samples are analyzed differ. However, in most cases up-regulation of different immune genes occurred and the down-regulation of many other genes was also evident, as already shown [31].

In order to define the response to the parasite, special attention was paid to differentially expressed genes (upand down-regulated genes) of biological processes statistically enriched in the infected groups, and the reliability of the results was validated by qPCR of selected key genes representative of the four clusters. The enzyme arginase-1 was representative of the strongly upregulated genes of cluster 1 in infected fish. Enhanced expression of this gene was also detected in the head kidney of Atlantic salmon and common carp (Cyprinus carpio) challenged with the bacterium Aeromonas salmonicida and the protozoan parasite Trypanosoma carasii, respectively $[30,40]$. The so-called "alternatively" activated macrophages play important roles in the clearance of pathogens (as reviewed in [41]), and their enhanced arginase activity allows them to produce ornithine, a precursor of hydroxyproline and polyamines. A first enzyme step is that of ornithine decarboxylase 
(ODC), though ornithine can also be produced from glutamate via ornithine aminotransferase (OAT). Interestingly, in our experimental model both ODC and OAT were up-regulated and belong to cluster 2, which confirms and extend the idea of an enhanced production of polyamines in the fish challenged with $E$. leei.

Polyamines have a significant effect on the growth of the gastrointestinal mucosa of a variety of organisms including fish [42], and the in vitro immunostimulatory action of putrescine has been observed in head kidney leukocytes of GSB [43]. Therefore, the increased expression of these genes involved in cell proliferation in infected GSB should be interpreted as an evidence of the regenerative action of the intestinal tissue as a response to the damage induced by the parasite invasion. L-arginine is also the substrate for the synthesis of nitric oxide (NO) by the catalytic action of $\mathrm{NO}$ synthases. Thus, if L-arginine is mainly used by arginase- 1 in ornithine synthesis, the production of NO should be expected to be reduced, and this is exactly what occurred in the serum NO levels of infected fish [12]. NO is an important molecule in regulating immune functions and also has a direct antimicrobial effect [44]. However, NO has double-edge sword effects [45], since an elevated production of NO for long periods of time not only can have the desirable protective action against the pathogen, but also can lead to a higher concentration of $\mathrm{NO}$ available to react with $\mathrm{O}_{2}$, increasing the production of reactive nitrogen species (RNS) and generating indirect toxic effects on the host. Since reactive oxygen species (ROS) were enhanced in infected fish (increased respiratory burst of circulating leukocytes) [12], it is a reasonable conservative strategy to reduce RNS to avoid detrimental effects to the host.

In cluster 2, several molecular chaperones (mitochondrial $10 \mathrm{kDa}$ and $60 \mathrm{kDa}$ heat shock proteins, glucoseregulated protein 75 , heat shock $70 \mathrm{kDa}$ protein 4 , mitochondrial chaperone BCS1, proteasome assembly chaperone 3) were up-regulated in the infected fish. The role of these life essential proteins is to stabilize unfolded proteins, often coupling ATP binding/hydrolysis to the folding process. Thus, their expression is often increased by cellular stress, as occurs with heat shock proteins of the HSP70 family, which are highly inducible under stress conditions in higher vertebrates [46] and also in fish [47]. Glucose-regulated protein 75 , also named mortalin or mitochondrial HSP70, is one of the molecular chaperones representative of this cluster and their enhanced expression was coincident with the upregulation of several mitochondrial ATP synthases, included in the same cluster. This finding is consistent with previous results analyzing the gene expression pattern of some target growth, redox and immune-relevant genes in the intestine of GSB [14]. The up-regulated expression of mortalin at the mRNA and protein level has also been observed in the liver tissue of GSB during both acute and chronic confinement stress [48], which emphasizes the relevance of this mitochondrial protein encoded by nuclear DNA as a stress biomarker in this fish species. Interestingly, no changes in mortalin expression were observed in the gills of Atlantic salmon infected with the protozoan Neoparamoeba perurans, the causative agent of amoebic gill disease, but resistant animals exposed but not infected with the parasite showed a significant up-regulation of mortalin expression [49], which evidences a complex and perhaps species-specific protective role of this protein in front of different stressors. Cluster 2 also comprised several immune-related genes, and the expression pattern of some of them, including IL6, IL6 receptor and peroxiredoxin 1 (also named natural killer enhancing factor-A), was validated by qPCR. Their up-regulation probably reflects the activation of innate immune response at the local site of infection. Similarly, in other fish-parasite models, up-regulation of different immune genes, mainly chemokines, cytokines, lectins and enzymes of eicosanoid metabolism, have been reported at the local site of infection (gills, skin, cartilage) [50-55].

Cluster 3 grouped genes severely down-regulated by infection. Among them, genes involved in xenobiotic metabolism and detoxification pathways were represented by cytochromes P450 and metallothionein. Since an increasing body of evidence points to the importance of intestine as a xenobiotic-metabolizing tissue [56], this decreased gene expression should be viewed as a counter-regulatory response that maintains the redox balance between the mechanisms bringing about the pathogen elimination and those governing the growth and repair of damaged tissues in a scenario where ROS production is potentiated in response to the parasite [12]. Another group of genes related to lipid metabolism (FABP2, liver $\mathrm{X}$ receptor alpha, phospholipase A2) and other established markers of metabolic activity in GSB, such as UCP1 and peroxiredoxin 6 [57,58], were also down-regulated in cluster 3 . Their reduced expression with infection is also suggestive of the loss of intestinal functions. This was further corroborated by pathway analysis of the differentially expressed genes during infection and by the down-regulation in cluster 4 of components of the somatotropic axis (GHR-I, GHR-II, IGF-II, IGFBP4) of importance in intestinal growth and repair [59], that can be considered a prelude to the severe cachectic episodes typically associated with more advanced stages of $E$. leei infection.

Some genes stand out of the general trend of higher regulation (either up or down) with longer infection time, as shown in Figure 3. This was the case for immunoglobulins, whose production was more up-regulated 
than expected in early-infected fish. This is consistent with the fact that the specific immune response takes more time to appear in fish than in higher vertebrates [60] and this time is particularly extended in this fishparasite model. In fact, it has been shown that time of exposure to E. leei is the most determinant factor for the intestine expression of immunoglobulin $\mathrm{M}$, the major component of fish specific humoral response, and this response is also magnified in 66VO fish [61]. In any case, we cannot discard the possible action of another Ig isotype, IgT/IgZ, which seems to act exclusively in mucosal areas, and has been described in very few fish species, with outstanding results in another myxosporean infection [62], but not yet found in GSB nor present in the current microarray. On the other hand, some genes related to complement pathways were strongly downregulated, which agrees with the previously observed down-regulation in E. leei-exposed GSB, although timing of infection was not considered [15]. These observations reflect the exhaustion of the alternative complement pathway also reported in other Enteromyxum spp. chronic infections $[13,63,64]$.

Taking together all these results, it appears that the changes detected in the intestine transcriptome are mostly a consequence rather than a cause of the different disease progression, so the differentially expressed genes can function as diagnostic markers of disease progression but lack a prognostic value to predict in advance the susceptibility of diet groups to an infective scenario. Although we did not find any transcriptomic differences in the intestine of the control groups through this microarray approach, other possibilities rather than a lack of effect of a differential diet on the intestinal gene expression profile must be considered to explain this result: (i) technical limitation of our microarray to detect significant differences in the expression of some genes, (ii) absence of genes with potential prognostic value in our nucleotide database or the resulting microarrays, or (iii) differences between groups could be due to nontranscriptional mediated processes. Further work is under way in order to achieve a more complete picture of the transcriptome of GSB. For instance, nextgeneration sequencing techniques (454 pyrosequencing) have been applied to normalized libraries from several GSB tissues including intestine, yielding millions of new nucleotide reads that will update and enrich in thousands of genes our GSB nucleotide database. Thus, the potential for the detection of changes in the expression of new genes will be greatly increased in future studies.

Finally, in this and other related works where the fish transcriptome response to an infective pathogen is observed, the transcriptome response is focused exclusively on the host [65-67], but the direct effects of diet composition and nutrients on parasite physiology and survival should also be considered, as it has been in the case of the direct effect of FAs as antimalarial agents where a direct effect on the FA biosynthetic machinery of the parasite Plasmodium falciparum has been shown [68]. It must be noted that most oils of vegetable origin are less susceptible to oxidative degradation than fish oils due to their lower content of very-long-chain $n-3$ polyunsaturated fatty acids [69], so parasite fatty acid uptake when feeding with FO diet could make it more sensitive to oxidative stress and consequently to the immune host response.

\section{Conclusions}

Plant oils in plant protein-based diets did not modify the intestine transcriptome of GSB, although there were significant effects when these fish were exposed to a parasite challenge with the myxosporean $E$. leei. The detected changes are mostly a consequence rather than a cause of the different disease progression in the two diet groups. The microarray approach as used here constitutes an excellent diagnostic tool to address changes associated with the action of intestinal pathogens, but lacks a prognostic value to predict in advance the susceptibility of different diet groups to this pathogen. Further studies are needed to explore the mechanisms involved in the altered susceptibility of GSB against the parasite $E$. leei when fed different diets, without excluding direct effects of fish feeds on parasite metabolism.

\section{Methods}

\section{Experimental design}

Details of the experimental design and sampling procedure have been provided previously [12]. Briefly, naïve juvenile fish were checked for the absence of the parasite and divided in two experimental groups fed over 9 months two different diets Additional file (2: Table S2) with either fish oil (FO diet) or a blend of vegetable oils (66VO diet, $66 \%$ fish oil replacement) as the major source of dietary lipids. After this period, fish from both diet groups were exposed to $E$. leei-water effluent (recipient group, $\mathrm{R}, \mathrm{n}=30$ ) or kept unexposed (control group, $\mathrm{C}, \mathrm{n}=30$ ). All fish were individually tagged with passive integrated transponders and nonlethally sampled at three consecutive times $(32,53,88$ days) for parasite diagnosis. In a final lethal sampling at 102 days post exposure (p.e.), fish were euthanized for tissue sampling and posterior intestine was rapidly excised, frozen in liquid nitrogen and stored at $-80^{\circ} \mathrm{C}$. All procedures were carried out according to national (CSIC, Institute of Aquaculture Torre de la Sal Review Board) and current EU legislation on the handling of experimental animals. 


\section{Parasite diagnosis}

Parasite diagnosis was performed by PCR from nonlethal samples obtained at different times (32, 53, 88 days) post-challenge by probing the rectum with a cotton swab as described in [70]. At the final lethal sampling (102 days), parasite diagnosis was performed in intestine samples by observation of histological sections following standard procedures (haematoxylin and eosin staining on paraffin-embedded sections). More details in [12].

As fish are infected by water effluent, the kinetics of the infection may differ in each individual. Thus, fish tagging and non-lethal diagnosis allowed the individualized monitoring of infection along the experimental period and the classification of $\mathrm{R}$ fish according to their first infection-timing in two categories: early infected (FO-INF $F_{\mathrm{E}}$ and $66 \mathrm{VO}-\mathrm{INF}_{\mathrm{E}}$ groups), being infected at 32 or 53 days p.e., and late infected $\left(\mathrm{FO}-\mathrm{INF}_{\mathrm{E}}\right.$ and $66 \mathrm{VO}-$ $\mathrm{INF}_{\mathrm{E}}$ groups), being infected at 88 days p.e. or later. Early infected fish had higher intensity of infection and extension of the infection than late infected ones. Fish non-exposed to the parasite (FO-C and 66VO-C groups) remained uninfected throughout the experiment.

\section{Construction of SSH libraries}

Total RNA was extracted using a Qiazol and RNeasy Maxi combination protocol (Qiagen) from liver and adipose tissue of fish fed FO and VO with signs of essential FA deficiencies (total fish oil replacement) [1]. Transcripts of mRNA were purified from total RNA using an Illustra Quickprep Micro mRNA purification kit (GE Healthcare). The mRNA populations were quantified by spectrophotometric measurements at $260 \mathrm{~nm}$ and analyzed for quality by the Agilent 2100 bioanalyzer (Agilent). Construction of SSH libraries was performed by means of the BD PCR Select cDNA Subtraction Kit (BD Biosciences Clontech). Briefly, two $\mu \mathrm{g}$ of mRNA were used to generate tester and driver cDNA. Then, both cDNAs were digested with Rsa I, tester cDNA was ligated to adaptor, and tester and driver cDNA were hybridized and PCR amplified. Aliquots $(1.5 \mu \mathrm{l})$ of secondary PCR products from subtracted cDNA populations were ligated to the pCR2.1 vector using the TA Cloning Kit (Invitrogen). Aliquots of ligation reactions were transformed into competent Top10 E. coli cells. Sequencing of SSH libraries (5,760 clones) was carried out at the Max Planck Institute of Molecular Genetics (Berlin, Germany), using ABI 3730XL (Applied Biosystems) and MegaBACE 4500 (GE Healthcare) capillary sequencer systems. All sequencing reactions were carried out with ABI BigDye Terminator version 3.1.

\section{Sequence assembly and annotation}

The cDNA sequences from SSH libraries were edited to remove vector and adaptor sequences, cleaned and filtered before clustering and annotation by the SIGENAE platform (INRA Toulouse, France). Cleaning involved masking of poor quality bases and low complexity sequences such as polyA tails. Filtering removed contaminating sequences (bacteria, yeast) and only high quality sequences of more than 100 bases in length were retained and deposited in the NCBI GenBank database [accession numbers GW820255-GW824593]. After combination with public and private GSB nucleotide sequences, a total number of 42,411 sequences were assembled in 20,218 contigs and singletons that were hosted in an exclusive GSB nucleotide database [http://www.sigenae.org/iats]. The SSH sequences from the present study amounted to 1,242 unique sequences (463 of which were new GSB sequences) and BLASTX similarity searches with a cut-off E-value of 1e-5 automatically annotated 7,587 sequences. GO analysis of all annotated sequences was made by means of the Blast2GO software [71], and GO terms like "response to stress", "lipid metabolic process" and "immune system process" were amongst the most prevalent GO categories (Additional file 3: Table S3).

\section{RNA extraction for microarray analysis}

Total RNA was extracted from individual intestine samples with the ABI PRISM ${ }^{\mathrm{Tm}} 6100$ Nucleic Acid PrepStation (Applied Biosystems). Samples were homogenized at a concentration of $25 \mathrm{mg} / \mathrm{ml}$ with a guanidine-detergent lysis reagent. The reaction mixture was treated with protease $\mathrm{K}$ and RNA purification was achieved by passing the tissue lysate $(0.4 \mathrm{ml})$ through a purification tray containing an application-specific membrane. Wash solutions containing DNase were applied and total RNA was eluted into a 96-well plate. The final RNA yield was 10$30 \mu \mathrm{g}$ and RIN (RNA integrity number) measurements using the Agilent 2100 Bioanalyzer ranged between 8 and 10 , which is indicative of clean and intact RNA.

\section{Microarray construction, hybridization and data analysis}

A custom high-density oligo-microarray (8 x 15K) was designed and printed (eArray web tool, Agilent) to analyze the intestine transcriptome of each diet group. The array comprised 2 sets of 60-oligomer probes for 7,500 GSB annotated sequences. Total RNA (200 ng) from individual fish $(\mathrm{n}=9$ for each control group and $\mathrm{n}=6$ for each recipient group) were labelled with cyanine 3-CTP, and 1,000 ng of each labelled cRNA were hybridized to microarray slides that were analyzed with an Agilent G2565BA Microarray Scanner according to the manufacturer's protocol. Data were extracted using the Agilent Feature Extraction Software 9.5.3, and they were deposited in the Gene Expression Omnibus (GEO) database under accession identifier GSE35633. Data analysis, including k-means clustering of differentially 
Table 1 Primer sequences for real-time qPCR validation

\begin{tabular}{|c|c|c|}
\hline Gene name & Symbol & Primer sequence \\
\hline \multirow[t]{2}{*}{ Arginase-1 } & \multirow[t]{2}{*}{ ARG1 } & F CGT CCA GTC CAC AGT CAG CAC \\
\hline & & R TCG GGC AGG CGG TAG TCC \\
\hline \multirow{2}{*}{$\begin{array}{l}\mathrm{B}(0,+) \text {-type amino } \\
\text { acid transporter } 1\end{array}$} & \multirow[t]{2}{*}{ BAT1 } & F GCC GTG TGT GCT TTG TTG CTG \\
\hline & & R GGT GAA GAT AAG GGC TGG AGA TGG \\
\hline \multirow{2}{*}{$\begin{array}{l}\text { Complement C1q } \\
\text { tumor necrosis } \\
\text { factor-related } \\
\text { protein } 3\end{array}$} & \multirow{2}{*}{ C1QTNF3 } & F ATG CTG TGC TGA GAG AGA TGA G \\
\hline & & R AGT CTT CTG CTT CTC CTG CTC \\
\hline \multirow{2}{*}{$\begin{array}{l}\text { Cytochrome } \\
\text { P450 1A1 }\end{array}$} & \multirow[t]{2}{*}{ CYP1A1 } & F GCA TCA ACG ACC GCT TCA ACG C \\
\hline & & $\begin{array}{l}\text { R CCT ACA ACC TTC TCA TCC GAC ATC } \\
\text { TGG }\end{array}$ \\
\hline \multirow{2}{*}{$\begin{array}{l}\text { Fatty acid-binding } \\
\text { protein, intestinal }\end{array}$} & \multirow{2}{*}{ FABP2 } & F CGA GCA CAT TCC GCA CCA AAG \\
\hline & & R CCC ACG CAC CCG AGA CTT C \\
\hline \multirow{2}{*}{$\begin{array}{l}\text { Glucose regulated } \\
\text { protein } 75\end{array}$} & \multirow{2}{*}{ GRP75 } & F TCC GGT GTG GAT CTG ACC AAA GAC \\
\hline & & R TGT TTA GGC CCA GAA GCA TCC ATG \\
\hline \multirow{2}{*}{$\begin{array}{l}\text { Growth hormone } \\
\text { receptor type I }\end{array}$} & \multirow[t]{2}{*}{ GHR-I } & F ACC TGT CAG CCA CCA CAT GA \\
\hline & & R TCG TGC AGA TCT GGG TCG TA \\
\hline \multirow{2}{*}{$\begin{array}{l}\text { Growth hormone } \\
\text { receptor type II }\end{array}$} & \multirow[t]{2}{*}{ GHR-II } & F GAG TGA ACC CGG CCT GAC AG \\
\hline & & R GCG GTG GTA TCT GAT TCA TGG T \\
\hline \multirow{2}{*}{$\begin{array}{l}\text { Immunoglobulin } \\
\text { lambda-like } \\
\text { polypeptide } 1\end{array}$} & \multirow[t]{2}{*}{ IGLL1 } & F TGA GTG GTG TGA CGG TGG TG \\
\hline & & R ATG GTG GCT GTC TCT CCT TTG G \\
\hline \multirow[t]{2}{*}{$\begin{array}{l}\text { Immunoglobulin } \\
\text { M heavy chain }\end{array}$} & \multirow[t]{2}{*}{ IGHM } & $\begin{array}{l}\text { F ACC TCA GCG TCC TTC AGT GTT TAT } \\
\text { GAT GCC }\end{array}$ \\
\hline & & R CAG CGT CGT CGT CAA CAA GCC AAG C \\
\hline \multirow{2}{*}{$\begin{array}{l}\text { Insulin-like growth } \\
\text { factor-II }\end{array}$} & \multirow{2}{*}{ IGF-II } & F TGG GAT CGT AGA GGA GTG TTG T \\
\hline & & R CTG TAG AGA GGT GGC CGA CA \\
\hline \multirow{2}{*}{$\begin{array}{l}\text { Insulin-like growth } \\
\text { factor-binding } \\
\text { protein } 4\end{array}$} & \multirow{2}{*}{ IGFBP4 } & F GGC ATC AAA CAC CCG CAC AC \\
\hline & & R ATC CAC GCA CCA GCA CTT CC \\
\hline \multirow[t]{2}{*}{ Interleukin-6 } & \multirow[t]{2}{*}{ IL6 } & F TCT TGA AGG TGG TGC TGG AAG TG \\
\hline & & R AAG GAC AAT CTG CTG GAA GTG AGG \\
\hline \multirow{2}{*}{$\begin{array}{l}\text { Interleukin-6 } \\
\text { receptor } \\
\text { subunit beta }\end{array}$} & IL6R $\beta$ & F AGC ACT GAG TCT CCG TAT GAA GC \\
\hline & & R ACA ACT GAA ACC GCA TCT AAA GGC \\
\hline receptor & LXRa & F GCA CTT CGC CTC CAG GAC AAG \\
\hline & & R CAG TCT TCA CAC AGC CAC ATC AGG \\
\hline Metallothionein & MT & F CTC TAA GAC TGG AAC CTG \\
\hline & & R GGG CAG CAT GAG CAG CAG \\
\hline & OAT & F TGC GGT CTG AGC TGA ACA A \\
\hline & & R CTT CCA GGC GTC GTA GTC T \\
\hline Ornithine & ODC & F GCC TCG TGT CAC TCC CTT CTA TG \\
\hline & & R GCT GAA TCT CCG TCT TGC TTG C \\
\hline Peroxiredoxin 1 & PRDX1 & F CTC CAA GCA ATA ATA AGC CCA AAG \\
\hline & & R TCA CTC TAC AGA CAA CAG AAC AC \\
\hline Peroxiredoxin 6 & PRDX6 & F AGA GAC AAG GAC GGA ATG C \\
\hline & & R TGT GGC GAC CTT CTT CTG \\
\hline & UCP1 & F GCA CAC TAC CCA ACA TCA CAA G \\
\hline
\end{tabular}

Table 1 Primer sequences for real-time qPCR validation (Continued)

\begin{tabular}{ll}
\hline $\begin{array}{l}\text { Uncoupling } \\
\text { protein 1 }\end{array}$ & R CGC CGA ACG CAG AAA CAA AG \\
B-Actin & F TCC TGC GGA ATC CAT GAG A \\
& R GAC GTC GCA CTT CAT GAT GCT \\
\hline
\end{tabular}

expressed genes, was carried out with the GeneSpring GX 11.5.1 software (Agilent). GO and Fisher enrichment analyses of k-means clusters were carried out by means of Blast2GO software. Pathway analysis of differentially expressed sequences was performed using the Ingenuity Pathway Analysis (IPA) software.

\section{Real-time qPCR validation}

Up to 21 genes representative of the four k-means clusters of differentially expressed genes were validated on individual samples $(n=6-9)$ by real-time qPCR, using an iCycler IQ Real-time Detection System (Bio-Rad). Synthesis of cDNA was performed with the High-Capacity cDNA Archive Kit (Applied Biosystems) using random decamers. For this purpose, $500 \mathrm{ng}$ total RNA were reverse transcribed in a final volume of $100 \mu \mathrm{l}$. RT reactions were incubated $10 \mathrm{~min}$ at $25^{\circ} \mathrm{C}$ and $2 \mathrm{~h}$ at $37^{\circ} \mathrm{C}$. Negative control reactions were incubated in the absence of reverse transcriptase. Diluted RT reactions were conveniently used for PCR reactions in $25 \mu \mathrm{l}$ volume. Each PCR-well contained a SYBR Green Master Mix (Bio-Rad) and specific primers (Table 1) were used at a final concentration of $0.9 \mu \mathrm{M}$. DNA Polymerase was activated and cDNA denatured by preincubation for $3 \mathrm{~min}$ at $95^{\circ} \mathrm{C}$; the template was amplified for 40 cycles of denaturation for $15 \mathrm{~s}$ at $95^{\circ} \mathrm{C}$, and annealing/extension at $60^{\circ} \mathrm{C}$ for $60 \mathrm{~s}$. $\beta$-Actin was used as the housekeeping gene and the efficiency of PCR reactions for target and reference genes varied between $90 \%$ and $98 \%$. The dynamic range of standard curves (serial dilutions of RT-PCR reactions) spanned five orders of magnitude, and the amount of product in a particular sample was determined by interpolation of the cycle threshold $(\mathrm{Ct})$ value. The specificity of reaction was verified by analysis of melting curves and by electrophoresis and sequencing of PCR amplified products. Fluorescence data acquired during the extension phase were ultimately normalized to $\beta$-actin by the $\Delta \Delta C$ t method [72]. For each selected gene, fold-change variations were calculated for FO-INF $\mathrm{I}_{\mathrm{E}}$ and $66 \mathrm{VO}-\mathrm{INF}_{\mathrm{E}}$ using expression values of FO$\mathrm{C}$ group as reference.

\section{Statistical analysis}

Microarray results from the six experimental groups (FOC, 66VO-C, FO-INF, , 66VO-INF ${ }_{\mathrm{E}}$, FO-INF,, $66 \mathrm{VO}-\mathrm{INF}_{\mathrm{E}}$ ) were analyzed by one-way ANOVA (corrected P-value $<0.05$, 
Benjamini-Hochberg) and principal components analysis by means of GeneSpring software.

\section{Additional files}

Additional file 1: Table S1. Sets of differentially expressed genes composing clusters 1-4. For each gene, fold-change values of experimentally expressed groups referred to FO-C group are represented.

Additional file 2: Table S2. Ingredients and chemical composition of experimental diets.

Additional file 3: Table S3. Top biological functions (GO multilevel) represented on the gilthead sea bream oligo-microarray.

\section{Competing interests}

The authors declare that they have no competing interests.

\section{Authors' contributions}

JPS, SK and ASB conceived and designed the study. ASB designed and performed the parasite infection and diagnosis. JACG, ASB and JPS sampled the experimental animals. GCD and MTC produced the SSH libraries. JACG and JPS designed the microarray and performed GeneSpring, statistical, gene ontology and pathway analyses. JACG validated microarray data by qPCR. JACG, ASB and JPS wrote the manuscript. All authors read and approved the final manuscript.

\section{Acknowledgements}

This work was funded by EU through projects AQUAMAX (FOOD-CT-200616249; Sustainable Aquafeeds to Maximise the Health Benefits of Farmed Fish for Consumers) and ARRAINA (Advanced Research Initiatives for Nutrition \& Aquaculture, FP7/2007/2013; grant agreement $n^{\circ}$ 288925), and by the Spanish Ministry of Science and Innovation (MICINN) through the projects AGL2009-13282-C02-01 and AQUAGENOMICS (CSD2007-00002, Improvement of Aquaculture Production by the Use of Biotechnological Tools). Additional funding was obtained from the "Generalitat Valenciana" (research grant PROMETEO 2010/006). The authors thank J. Monfort and L. Rodríguez for histological processing and M.A. González for technical assistance during gene expression analyses.

\section{Author details}

${ }^{1}$ Nutrigenomics and Fish Growth Endocrinology Group, Department of Marine Species Biology, Culture and Pathology, Instituto de Acuicultura Torre de la Sal (IATS-CSIC), Ribera de Cabanes, Castellón 12595, Spain. ${ }^{2}$ Fish Pathology Group, Department of Marine Species Biology, Culture and Pathology, Instituto de Acuicultura Torre de la Sal (IATS-CSIC), Ribera de Cabanes, Castellón 12595, Spain. ${ }^{3}$ Ryan Institute, National University of Ireland, Galway, Ireland. ${ }^{4}$ INRA, UR1067 NuMeA Nutrition, Metabolism Aquaculture, Saint Pée-sur, Nivelle F64310, France.

Received: 1 June 2012 Accepted: 7 September 2012 Published: 11 September 2012

\section{References}

1. Benedito-Palos L, Saera-Vila A, Calduch-Giner JA, Kaushik S, Pérez-Sánchez J: Combined replacement of fish meal and oil in practical diets for fast growing juveniles of gilthead sea bream (Sparus aurata L.): Networking of systemic and local components of GH/IGF axis. Aquaculture 2007, 267:199-212.

2. Benedito-Palos L, Navarro JC, Sitjà-Bobadilla A, Bell JG, Kaushik S, PérezSánchez J: High levels of vegetable oils in plant protein-rich diets fed to gilthead sea bream (Sparus aurata L.): growth performance, muscle fatty acid profiles and histological alterations of target tissues. Brit J Nutr 2008, 100:992-1003.

3. Benedito-Palos L, Navarro JC, Kaushik S, Pérez-Sánchez J: Tissue-specific robustness of fatty acid signatures in cultured gilthead sea bream (Sparus aurata L.) fed practical diets with a combined high replacement of fish meal and fish oil. J Anim Sci 2010, 88:1759-1770.

4. Benedito-Palos L, Bermejo-Nogales A, Karampatos Al, Ballester-Lozano GF, Navarro JC, Diez A, Bautista JM, Bell JG, Tocher DR, Obach A, Kaushik S,
Pérez-Sánchez J: Modelling the predictable effects of dietary lipid sources on the fillet fatty acid composition of one-year-old gilthead sea bream (Sparus aurata L.). Food Chem 2011, 124:538-544.

5. Ballester-Lozano GF, Benedito-Palos L, Navarro JC, Kaushik S, Pérez-Sánchez J: Prediction of fillet fatty acid composition of market-size gilthead sea bream (Sparus aurata) using a regression modelling approach. Aquaculture 2011, 319:81-88.

6. Benedito-Palos L, Navarro JC, Bermejo-Nogales A, Saera-Vila A, Kaushik S, Pérez-Sánchez J: The time-course of fish oil wash-out follows a simple dilution model in gilthead sea bream (Sparus aurata L.) fed graded levels of vegetable oils. Aquaculture 2009, 288:98-105.

7. Oliva-Teles A: Nutrition and health of aquaculture fish. J Fish Dis 2012, 35:83-108.

8. Trichet W: Nutrition and immunity: an update. Aquac Res 2010, 41:356-372.

9. Montero $D$, Izquierdo $M$ : Welfare and health of fish fed vegetable oils as alternative lipid sources to fish oil. In Fish oil replacement and alternative lipid sources in aquaculture feeds. Edited by Turchini GM, Wing-Keong N, Tocher DR. Boca Raton: CRC Press; 2010:439-485.

10. Saera-Vila A, Benedito-Palos L, Sitjà-Bobadilla A, Nácher-Mestre J, Serrano R, Kaushik S, Pérez-Sánchez J: Assessment of the health and antioxidant trade-off in gilthead sea bream (Sparus aurata L.) fed alternative diets with low levels of contaminants. Aquaculture 2009, 296:87-95.

11. Ganga R, Montero D, Bell JG, Atalah E, Ganuza E, Vega-Orellana O, Tort L, Acerete L, Afonso JM, Benitez-Sanatana T, Fernández Vaquero A, Izquierdo M: Stress response in sea bream (Sparus aurata) held under crowded conditions and fed diets containing linseed and/or soybean oil. Aquaculture 2011, 311:215-223.

12. Estensoro I, Benedito-Palos L, Palenzuela O, Kaushik S, Sitjà-Bobadilla A, Pérez-Sánchez J: The nutritional background of the host alters the disease course in a fish-myxosporean system. Vet Parasitol 2011, 175:141-150.

13. Cuesta A, Muñoz P, Rodríguez A, Salinas I, Sitjà-Bobadilla A, Álvarez-Pellitero P, Esteban MA, Meseguer J: Gilthead seabream (Sparus aurata L.) innate defence against the parasite Enteromyxum leei (Myxozoa). Parasitology 2006, 132:95-104

14. Sitjà-Bobadilla A, Calduch-Giner J, Saera-Vila A, Palenzuela O, ÁlvarezPellitero P, Pérez-Sánchez J: Chronic exposure to the parasite Enteromyxum leei (Myxozoa: Myxosporea) modulates the immune response and the expression of growth, redox and immune relevant genes in gilthead sea bream, Sparus aurata L. Fish Shellfish Immunol 2008, 24:610-619.

15. Davey GC, Calduch-Giner JA, Houeix B, Talbot A, Sitjà-Bobadilla A, Prunet P, Pérez-Sánchez J, Cairns MT: Molecular profiling of the gilthead sea bream (Sparus aurata L.) response to chronic exposure to the myxosporean parasite Enteromyxum leei. Mol Immunol 2011, 48:2102-2212.

16. Calduch-Giner JA, Davey G, Saera-Vila A, Houeix B, Talbot A, Prunet P, Cairns MT, Pérez-Sánchez J: Use of microarray technology to assess the time course of liver stress response after confinement exposure in gilthead sea bream (Sparus aurata L.). BMC Genomics 2010, 11:193.

17. Douglas SE: Microarray studies of gene expression in fish. OMICS 2006 , 10:474-489.

18. Goetz FW, Mackenzie S: Functional genomics with microarrays in fish biology and fisheries. Fish Fish 2008, 9:378-395.

19. Prunet P, Overli O, Douxfils J, Bernardini G, Kestemont P, Baron D: Fish welfare and genomics. Fish Physiol Biochem 2012, 38:43-60.

20. Cairns MT, Johnson MC, Talbot AT, Pemmasani JK, MCNeill RE, Houeix B, Sangrador-Vegas A, Pottinger TG: A cDNA microarray assessment of gene expression in the liver of rainbow trout (Oncorhynchus mykiss) in response to a handling and confinement stressor. Comp Biochem Physiol D 2008, 3:51-66

21. Pemmasani JK, Pottinger TG, Cairns MT: Analysis of stress-induced hepatic gene expression in rainbow trout (Oncorhynchus mykiss) selected for high- and low-responsiveness to stress. Comp Biochem Physiol D 2011, 6:406-419.

22. Reynders $H$, Van der Ven $K$, Moens $L N$, Van Remortel P, De Coen WM, Blust R: Patterns of gene expression in carp liver after exposure to a mixture of waterborne and dietary cadmium using a custom-made microarray. Aquat Toxicol 2006, 80:180-193.

23. Gunnarsson L, Kristiansson E, Förlin L, Nerman O, Larsson DGJ: Sensitive and robust gene expression changes in fish exposed to estrogen - a microarray approach. BMC Genomics 2007, 8:149. 
24. Meland S, Farmen E, Heier LS, Rosseland BO, Salbu B, Song Y, Tollefsen KE: Hepatic gene expression profile in brown trout (Salmo trutta) exposed to traffic related contaminants. Sci Total Environ 2011, 409:1430-1443.

25. Jordal AEO, Torstensen BE, Tsoi S, Tocher DR, Lall SP, Douglas SE: Dietary rapeseed oil affects the expression of genes involved in hepatic lipid metabolism in Atlantic salmon (Salmo salar L.). J Nutr 2005, 135:2355-2361.

26. Geay F, Ferraresso S, Zambonino-Infante JL, Bargelloni L, Quentel C, Vandeputte M, Kaushik S, Cahu CL, Mazurais D: Effects of the total replacement of fish-based diet with plant-based diet on the hepatic transcriptome of two European sea bass (Dicentrarchus labrax) half-sibfamilies showing different growth rates with the plant-based diet. BMC Genomics 2011, 12:522

27. Morais S, Pratoomyot J, Taggart JB, Bron JE, Guy DR, Bell JG, Tocher DR: Genotype-specific responses in Atlantic salmon (Salmo salar) subject to dietary fish oil replacement by vegetable oil: a liver transcriptomic analysis. BMC Genomics 2011, 12:255.

28. Tacchi L, Bickerdike R, Douglas A, Secombes CJ, Martin SAM: Transcriptomic responses to functional feeds in Atlantic salmon (Salmo salar). Fish Shellfish Immunol 2011, 31:704-715.

29. Rise ML, Jones SRM, Brown GD, Von Schalburg KR, Davidson WS, Koop BF: Microarray analyses identify molecular biomarkers of Atlantic salmon macrophage and hematopoietic kidney response to Piscirickettsia salmonis infection. Physiol Genomics 2004, 20:21-35.

30. Fast MD, Tse B, Boyd JM, Johnson SC: Mutations in the Aeromonas salmonicida subsp. salmonicida type III secretion system affect Atlantic salmon leucocyte activation and downstream immune responses. Fish Shellfish Immunol 2009, 27:721-728.

31. Huang Y, Huang X, Yan Y, Cai J, Ouyang Z, Cui H, Wang P, Qin Q: Transcriptome analysis of orange-spotted grouper (Epinephelus coioides) spleen in response to Singapore grouper iridovirus. BMC Genomics 2011 12:556.

32. Cain K, Swan C: Barrier function and immunology. In Fish Physiology. Volume 30. Edited by Grosell M, Farrell AP, Brauner CJ. New York: Academic Press; 2010:111-134.

33. Rombout JHWM, Abelli L, Picchietti S, Scapigliati G, Kiron V: Teleost intestinal immunology. Fish Shellfish Immunol 2011, 31:616-626.

34. Kalujnaia S, McWilliam IS, Zaguinaiko VA, Feilen AL, Nicholson J, Hazon N, Cutler CP, Balment RJ, Cossins AR, Hughes M, Cramb G: Salinity adaptation and gene profiling analysis in the European eel (Anguilla anguilla) using microarray technology. Gen Comp Endocrinol 2007, 152:274-280.

35. Kirchner S, McDaniel NK, Sugiura SH, Soteropoulos P, Tian B, Fletcher JW, Ferraris RP: Salmonid microarrays identify intestinal genes that reliably monitor P deficiency in rainbow trout aquaculture. Anim Genet 2007 , 38:319-331.

36. Doñate C, Balasch JC, Callol A, Bobe J, Tort L, MacKenzie S: The effects of immunostimulation through dietary manipulation in the rainbow trout; evaluation of mucosal immunity. Mar Biotechnol 2010, 12:88-99.

37. Murray HM, Lall SP, Rajaselvam R, Boutilier LA, Blanchard B, Flight RM, Colombo S, Mohindra V, Douglas SE: A nutrigenomic analysis of intestinal response to partial soybean meal replacement in diets for juvenile Atlantic halibut, Hippoglossus hippoglossus, L. Aquaculture 2010, 298:282-293.

38. Skugor S, Grisdale-Helland B, Refstie S, Afanasyev S, Vielma J, Krasnov A: Gene expression responses to restricted feeding and extracted soybean meal in Atlantic salmon (Salmo salar L.). Aquacult Nutr 2011, 17:505-517.

39. Morais S, Edvardsen RB, Tocher DR, Bell JG: Transcriptomic analyses of intestinal gene expression of juvenile Atlantic cod (Gadus morhua) fed diets with Camelina oil as replacement for fish oil. Comp Biochem Physiol B 2012, 161:282-293.

40. Joerink M, Savelkoul HFJ, Wiegertjes GF: Evolutionary conservation of alternative activation of macrophages: structural and functional characterization of arginase 1 and 2 in carp (Cyprinus carpio L.). Mol Immunol 2006, 43:1116-1128.

41. Forlenza M, Fink IR, Raes G, Wiegertjes GF: Heterogeneity of macrophage activation in fish. Dev Comp Immunol 2011, 35:1246-1255.

42. Péres $\mathrm{A}$, Cahu $\mathrm{CL}$, Zambonino-Infante $\mathrm{JL}$ : Dietary spermine supplementation induces intestinal maturation in sea bass (Dicentrarchus labrax) larvae. Fish Physiol Biochem 1997, 16:479-485.
43. Reyes-Becerril M, Ascencio-Valle F, Tovar-Ramírez D, Meseguer J, Esteban MA: Effects of polyamines on cellular innate immune response and the expression of immune-relevant genes in gilthead seabream leucocytes. Fish Shellfish Immunol 2011, 30:248-254.

44. Campos-Perez JJ, Ellis AE, Secombes CJ: Toxicity of nitric oxide and peroxynitrite to bacterial pathogens of fish. Dis Aquat Org 2000, 43:109-115.

45. Thippeswamy T, Mckay JS, Quinn JP, Morris R: Nitric oxide, a biological double-faced Janus - Is this good or bad? Histol Histopathol 2006, 21:445-458.

46. Stetler RA, Gan Y, Zhang W, Liou AK, Gao Y, Cao G, Chen J: Heat shock proteins: Cellular and molecular mechanisms in the central nervous system. Prog Neurobiol 2010, 92:184-211.

47. Deane EE, Woo NYS: Advances and perspectives on the regulation and expression of piscine heat shock proteins. Rev Fish Biol Fisheries 2011, 21:153-185.

48. Bermejo-Nogales A, Benedito-Palos L, Saera-Vila A, Calduch-Giner JA, SitjàBobadilla A, Pérez-Sánchez J: Confinement exposure induces glucose regulated protein 75 (GRP75/mortalin/mtHsp70/PBP74/HSPA9B) in the hepatic tissue of gilthead sea bream (Sparus aurata L.). Comp Biochem Physiol B 2008, 149:428-438.

49. Wynne JW, O'Sullivan MG, Stone G, Cook MT, Nowak BF, Lovell DR, Taylor RS, Elliott NG: Resistance to amoebic gill disease (AGD) is characterised by the transcriptional dysregulation of immune and cell cycle pathways. Dev Comp Immunol 2008, 32:1539-1560.

50. Sigh J, Lindenstrom T, Buchmann K: The parasitic ciliate Ichthyophthirius multifiliis induces expression of immune relevant genes in rainbow trout, Oncorhynchus mykiss (Walbaum). J Fish Dis 2004, 27:409-417.

51. Lindenstrom T, Secombes CJ, Buchmann K: Expression of immune response genes in rainbow trout skin induced by Gyrodactylus derjavini infections. Vet Immunol Immunopathol 2004, 97:137-148.

52. Severin VIC, El Matbouli M: Relative quantification of immune-regulatory genes in two rainbow trout strains, Oncorhynchus mykiss, after exposure to Myxobolus cerebralis, the causative agent of whirling disease. Parasito Res 2007, 101:1019-1027.

53. Forlenza M, Walker PD, de Vries BJ, Wendelaar Bonga SE, Wiegertjes GF: Transcriptional analysis of the common carp (Cyprinus carpio L.) immune response to the fish louse Argulus japonicus Thiele (Crustacea: Branchiura). Fish Shellfish Immunol 2008, 25:76-83.

54. Li YW, Dan XM, Zhang TW, Luo XC, Li AX: Immune-related genes expression profile in orange-spotted grouper during exposure to Cryptocaryon irritans. Parasite Immunol 2011, 33:679-687.

55. Tadiso T, Krasnov A, Skugor S, Afanasyev S, Hordvik I, Nilsen F: Gene expression analyses of immune responses in Atlantic salmon during early stages of infection by salmon louse (Lepeophtheirus salmonis) revealed bi-phasic responses coinciding with the copepod-chalimus transition. BMC Genomics 2011, 12:141.

56. Van Herwaarden $A E$, Van Waterschoot RAB, Schinkel AH: How important is intestinal cytochrome P450 3A metabolism? Trends Pharmacol Sci 2009, 30:223-227

57. Bermejo-Nogales A, Calduch-Giner JA, Pérez-Sánchez J: Gene expression survey of mitocondrial uncoupling proteins (UCP1/UCP3) in gilthead sea bream (Sparus aurata L.). J Comp Physiol B 2010, 180:685-694.

58. Pérez-Sánchez J, Bermejo-Nogales A, Calduch-Giner JA, Kaushik S, SitjàBobadilla A: Molecular characterization and expression analysis of six peroxiredoxin paralogous genes in gilthead sea bream (Sparus aurata): insights from fish exposed to dietary, pathogen and confinement stressors. Fish Shellfish Immunol 2011, 31:294-302.

59. Theiss AL, Fruchtman S, Lund PK: Growth factors in inflammatory bowel disease. The actions and interactions of growth hormone and insulin-like growth factor-I. Inflamm Bowel Dis 2004, 10:871-880.

60. Magnadóttir B: Innate immunity of fish (overview). Fish Shellfish Immunol 2006, 20:137-151.

61. Estensoro I, Calduch-Giner JA, Kaushik S, Pérez-Sánchez J, Sitjà-Bobadilla A Modulation of the IgM gene expression and IgM immunoreactive cell distribution by the nutritional background in gilthead sea bream (Sparus aurata) challenged with Enteromyxum leei (Myxozoa). Fish Shellfish Immunol 2012, 33:401-410.

62. Zhang YA, Salinas I, Li J, Parra D, Bjork S, Xu Z, La Patra SE, Bartholomew J, Sunyer JO: IgT, a primitive immunoglobulin class specialized in mucosal immunity. Nat Immunol 2010, 11:827-835. 
63. Sitjà-Bobadilla A, Redondo M, Bermúdez R, Palenzuela O, Ferreiro I, Riaza A, Quiroga I, Nieto J, Álvarez-Pellitero P: Innate and adaptive responses of turbot, Scopththalmus maximus (L.) following experimental infection with Enteromyxum scophthalmi (Myxosporea: Myxozoa). Fish Shellfish Immunol 2006, 21:485-500.

64. Álvarez-Pellitero P, Palenzuela O, Sitjà-Bobadilla A: Histopathology and celular response in Enteromyxum leei (Myxozoa) infections of Diplodus puntazo (Teleostei). Parasitol Int 2008, 57:110-120.

65. Ewart KV, Belanger JC, Williams J, Karakach T, Penny S, Tsoi SCM, Richards RC, Douglas SE: Identification of genes differentially expressed in Atlantic salmon (Salmo salar) in response to infection by Aeromonas salmonicida using CDNA microarray technology. Dev Comp Immunol 2005, 29:333-347.

66. Peatman E, Terhune J, Baoprasertkul P, Xu P, Nandi S, Wang S, Somridhivej B, Kucuktas H, Li P, Dunham R, Liu Z: Microarray analysis of gene expression in the blue catfish liver reveals early activation of the MHC class I pathway after infection with Edwardsiella ictaluri. Mol Immunol 2008, 45:553-566.

67. Matsuyama T, Fujiwara A, Takano T, Nakayasu C: Suppression subtractive hybridization coupled with microarray analysis to examine differential expression of genes in Japanese flounder Paralichthys olivaceus leucocytes during Edwardsiella tarda and viral hemorrhagic septicemia virus infection. Fish Shellfish Immunol 2011, 31:524-532.

68. Carballeira NM: New advances in fatty acids as antimalarial, antimycobacterial and antifungal agents. Prog Lipid Res 2008, 47:50-61.

69. Turner R, McLean CH, Silvers KM: Are the health benefits of fish oils limited by products of oxidation? Nutr Res Rev 2006, 19:53-62.

70. Palenzuela O, Bartholomew JL: Molecular tools for the diagnosis of Ceratomyxa shasta (Myxozoa). In Molecular diagnosis of salmonid diseases. Cunningham CO. Dordrecht: Kluwer Academic Publishers; 2002:285-298.

71. Conesa A, Götz S, García-Gómez JM, Perol J, Talón M, Robles M: Blast2GO: a universal tool for annotation, visualization and analysis in functional genomics research. Bioinformatics 2005, 21:3674-3676.

72. Livak KJ, Schmittgen TD: Analysis of relative gene expression data using real-time quantitative PCR and the $22_{\mathrm{T}}^{-\Delta \Delta C}$ method. Methods 2001, 25:402-408

doi:10.1186/1471-2164-13-470

Cite this article as: Calduch-Giner et al.: Dietary vegetable oils do not alter the intestine transcriptome of gilthead sea bream (Sparus aurata) but modulate the transcriptomic response to infection with Enteromyxum leei. BMC Genomics 2012 13:470

\section{Submit your next manuscript to BioMed Central and take full advantage of:}

- Convenient online submission

- Thorough peer review

- No space constraints or color figure charges

- Immediate publication on acceptance

- Inclusion in PubMed, CAS, Scopus and Google Scholar

- Research which is freely available for redistribution 